\title{
An oligarchic microbial assemblage in the anoxic bottom waters of a volcanic subglacial lake
}

Éric Gaidos ${ }^{1,2}$, Viggo Marteinsson ${ }^{3}$, Thorsteinn Thorsteinsson ${ }^{4}$, Tomas Jóhannesson ${ }^{5}$, Árni Rafn Rúnarsson ${ }^{3}$, Andri Stefansson ${ }^{6}$, Brian Glazer ${ }^{7}$, Brian Lanoil ${ }^{8,11}$, Mark Skidmore ${ }^{9}$, Sukkyun Han $^{8}$, Mary Miller ${ }^{10}$, Antje Rusch ${ }^{1}$ and Wilson Foo ${ }^{8}$

${ }^{1}$ Department of Geology and Geophysics, University of Hawaii at Manoa, Honolulu, HI, USA; ${ }^{2}$ NASA Astrobiology Institute, Mountain View, CA, USA; ${ }^{3}$ MATIS-Prokaria, Reykjavík, Iceland; ${ }^{4}$ Hydrological Service, National Energy Authority, Reykjavík, Iceland; ${ }^{5}$ Icelandic Meteorological Office, Reykjavík, Iceland; ${ }^{6}$ Science Institute, University of Iceland, Reykjavi'k, Iceland; ${ }^{7}$ Department of Oceanography, University of Hawaii, Honolulu, HI, USA; ${ }^{8}$ Department of Environmental Sciences, University of California at Riverside, Riverside, CA, USA; ${ }^{9}$ Department of Earth Sciences, Montana State University, Bozeman, MT, USA and ${ }^{10}$ Department of Microbiology and Immunology, University of Texas Medical Branch, Galveston, TX, USA

\begin{abstract}
In 2006, we sampled the anoxic bottom waters of a volcanic lake beneath the Vatnajökull ice cap (Iceland). The sample contained $5 \times 10^{5}$ cells per $\mathrm{ml}$, and whole-cell fluorescent in situ hybridization (FISH) and PCR with domain-specific probes showed these to be essentially all bacteria, with no detectable archaea. Pyrosequencing of the V6 hypervariable region of the 16S ribosomal RNA gene, Sanger sequencing of a clone library and FISH-based enumeration of four major phylotypes revealed that the assemblage was dominated by a few groups of putative chemotrophic bacteria whose closest cultivated relatives use sulfide, sulfur or hydrogen as electron donors, and oxygen, sulfate or $\mathrm{CO}_{2}$ as electron acceptors. Hundreds of other phylotypes are present at lower abundance in our V6 tag libraries and a rarefaction analysis indicates that sampling did not reach saturation, but FISH data limit the remaining biome to $<10-20 \%$ of all cells. The composition of this oligarchy can be understood in the context of the chemical disequilibrium created by the mixing of sulfidic lake water and oxygenated glacial meltwater.
\end{abstract}

The ISME Journal (2009) 3, 486-497; doi:10.1038/ismej.2008.124; published online 18 December 2008

Subject Category: microbial ecology and functional diversity of natural habitats

Keywords: acetogenesis; anoxia; extreme environments; microbial diversity; psychrophily; sulfide oxidation

\section{Introduction}

Perennial lakes under the ice sheets of Antarctica (Siegert et al., 2005) and Iceland (Björnsson, 2002) are potential habitats for chemotrophic microbial communities tolerant of oligotrophic conditions, low temperatures and high pressures. They are plausible analogs of habitats on Mars and the icy satellites of the outer planets (Gaidos et al., 1999; Kennicut, 2000; Farr, 2004). In Iceland, volcanic heat maintains three lakes beneath the Vatnajökull ice cap (Björnsson, 2002). The largest $\left(\sim 20 \mathrm{~km}^{2}\right)$ lies

Correspondence: E Gaidos, Department of Geology and Geophysics, University of Hawaii at Manoa, 1680 East-West Road, Honolulu, HI 96822 USA.

E-mail: gaidos@hawaii.edu

${ }^{11}$ Current address: Department of Biological Sciences, University of Alberta, Edmonton, Canada

Received 24 September 2008; revised 5 November 2008; accepted 8 November 2008; published online 18 December 2008 within the Grímsvötn caldera and two smaller $\left(1 \mathrm{~km}^{2}\right)$ lakes (western and eastern Skaftá lakes) occupy the glacial divide separating Grímsvötn and the Báðarbunga volcano (Figure 1). Geothermal heat melts the overlying ice, creating a depression in the glacier surface that drives the restoring inward flow of ice. These lakes drain episodically in jökulhlaups (outburst floods) when rising water levels open a channel under an ice barrier.

Subglacial volcanic lakes differ markedly from their subaerial counterparts; the former are diluted by melting glacial ice while the latter experience evaporation and sunlight (Pasternack and Varekamp, 1997). The Grímsvötn lake is a cold $\left(-0.2^{\circ} \mathrm{C}\right)$, oligotrophic $\left(\sim 0.3 \mathrm{mg} \mathrm{l}^{-1}\right.$ particulate organic carbon), acidic ( $\mathrm{pH}$ 5.7-7.0) and fresh (total dissolved solids $=200 \mathrm{mg} \mathrm{l}^{-1}$ ) body of water with little apparent geothermal influence (Ágústsdóttir and Brantley, 1994; Gaidos et al., 2004). An analysis of samples from the water column and volcanic 


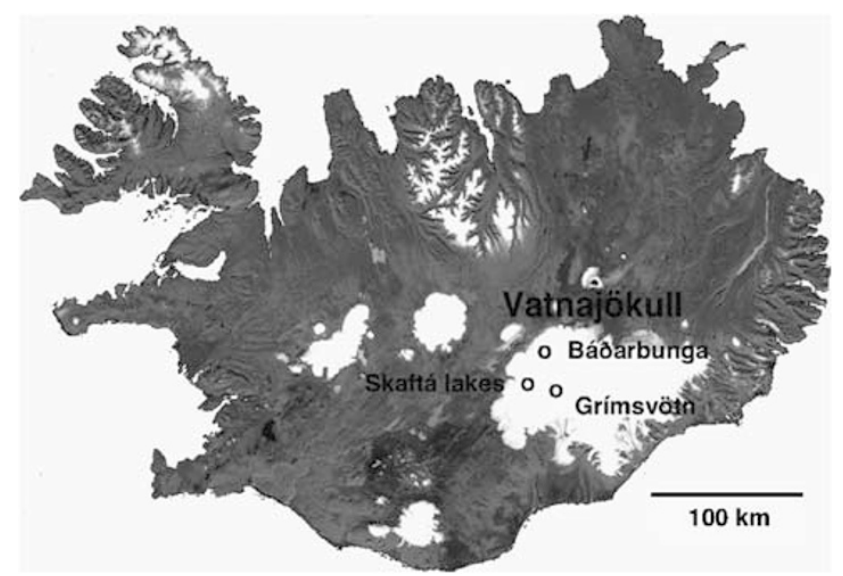

Figure 1 Location of the subglacial Grímsvötn and Skaftá lakes and the Báðarbunga volcano under the Vatnajökull ice cap, Iceland. Map based on a NASA image.

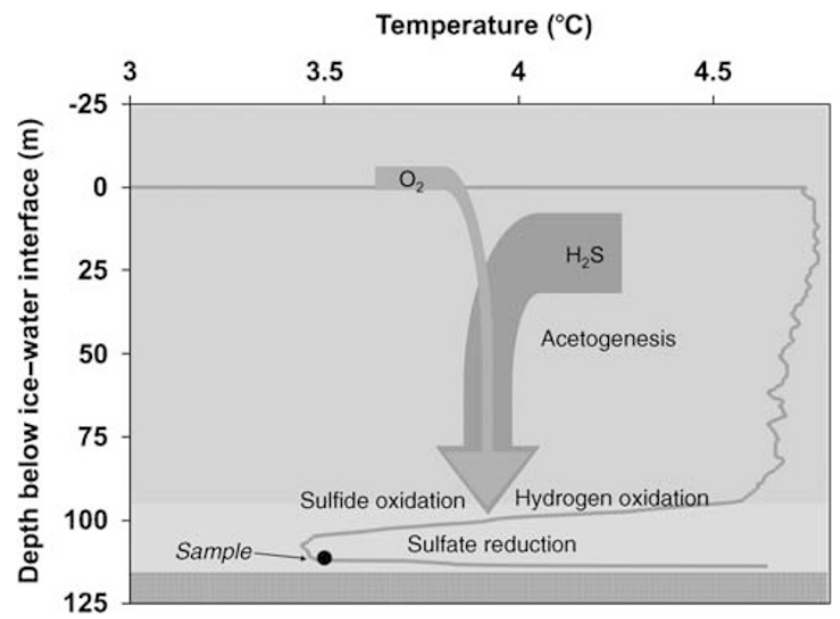

Figure 2 Diagram of the western Skaftá lake, showing the temperature profile on 19 June 2006 (Jóhannesson et al., 2007), and the overlying ice (light blue), anoxic water column (red) and the bottom water (magenta). The proposed mechanism of bottom water formation and important microbial metabolism are illustrated (see text for details). The location of the water sample is marked. The color reproduction of this figure is available on the $\mathrm{html}$ full text version of the manuscript.

tephra sediment found a diverse assemblage of microorganisms (that is, bacteria), some of which were cold tolerant or autotrophic, but with no evidence for adaptation to geothermal habitats (Gaidos et al., 2004). However, the chemistry and biology of subglacial volcanic lakes should reflect the relative input of oxygenated glacial melt and reducing geothermal fluid, and other systems may differ from Grímsvötn.

In June 2006, we obtained temperature profiles and a single water sample from the western Skaftá lake. At the location of our borehole $\left(66.4963^{\circ} \mathrm{N}\right.$, $17.6174^{\circ} \mathrm{W}$ ), the glacier was $300 \mathrm{~m}$ thick and the lake was $115 \mathrm{~m}$ deep. Temperatures were close to $4.7^{\circ} \mathrm{C}$ throughout the water column except for a $15-\mathrm{m}$ thick, colder $\left(3.5^{\circ} \mathrm{C}\right)$ bottom water mass overlying a warmer $\left(6{ }^{\circ} \mathrm{C}\right)$ 1- to 2-m thick layer (Figure 2) (Jóhannesson et al., 2007). The sample, collected from $3 \mathrm{~m}$ above the lake bottom, was anoxic $(<2 \mu \mathrm{M}$ $\mathrm{O}_{2}$ ) and contained $1.08 \mathrm{mM}$ total sulfide $\left(\mathrm{H}_{2} \mathrm{~S}+\mathrm{HS}^{-}\right)$, $0.16 \mathrm{mM}$ sulfate $\left(\mathrm{SO}_{4}^{2-}\right), 30 \mathrm{mM}$ dissolved $\mathrm{CO}_{2}$ and unquantified micromolar $\mathrm{H}_{2}$ (Jóhannesson et al., 2007). Using the temperature profile and thermodynamic constraints, Jóhannesson et al. (2007) concluded that the bottom water mass was a $6: 1$ mixture of glacial meltwater and sulfidic geothermal fluid. Here, we describe an assemblage of bacteria in the sample which was dominated by a few groups, some of which appear well adapted to this unique environment.

\section{Materials and methods}

\section{Drilling}

Hot water drilling was performed with the system described by Thorsteinsson et al. (2008). The design and operation of the drill minimized the potential for forward contamination of the lake and reverse contamination of samples, and included using snow $50 \mathrm{~m}$ upwind of the rig for drilling fluid, disposal of the upper meter of snow, a $50 \mu \mathrm{m}$ filter, an ultraviolet sterilization system, heating of the snowmelt to $>100{ }^{\circ} \mathrm{C}$ and flushing with several volumes of $70 \%$ ethanol before operation. Relative to a $\mathrm{diH}_{2} \mathrm{O}$ blank, direct counts of cells in samples decreased from $1.6 \times 10^{4}$ in snowmelt at the entrance to the filter to $4 \times 10^{3}$ per $\mathrm{ml}$ in the drilling water. Colony-forming units on plate count agar (3-7 d of incubation at $22^{\circ} \mathrm{C}$ ) decreased from 900 per $\mathrm{ml}$ at the entrance to the filter to undetectable $(<3$ per $\mathrm{ml})$ at the drill head (Thorsteinsson et al., 2008). The total concentration of cells in the drilling water was comparable with that in Vatnajökull ice (Table 3 in Gaidos et al. (2004)) and the number of colony-forming units was much less. About $1 \mathrm{~m}^{3}$ of borehole water may have entered the lake at penetration, less than the mass of basal ice melted by volcanic heat per second (Jóhannesson et al., 2007). Thus, any contamination of the lake was extremely minimal and consistent with the recommendations of the US National Research Council (2007).

\section{Sampling and chemical analyses}

We obtained a single $400 \mathrm{ml}$ sample using a custombuilt gas-tight sampler (Gaidos et al., 2007). The sampler was washed with $10 \% \mathrm{NaHClO}$ (30 min) immediately before borehole insertion. To check for sample contamination, $250 \mathrm{ml}$ of filtered, sterilized, 20\% Rhodamine WT dye (Keystone Aniline, Chicago, IL, USA) was added to a concentration of 25 p.p.m. in the borehole. This low-ecotoxicity dye (Jensen and Kristensen, 1999; Behrens et al., 2001) would eventually mix into the lake to a concentration of 1 p.p.t. and thus its use was consistent with the recommendations of the US National Research Council (2007). Negative visual detection of dye ( $<25$ p.p.b.) confirmed that any 
borehole contamination of our sample was $<1$ :1000. Supporting electrovoltammetry used a flow cell attached directly to the sampler (Supplementary Information). Particulate organic carbon and nitrogen were measured as described earlier (Gaidos et al., 2004).

\section{Cell counts}

Samples for cell counts and fluorescent in situ hybridization (FISH) were immediately mixed with 3 volumes of $4 \%, 0.2-\mu \mathrm{m}$ filtered paraformaldehyde solution ( $\mathrm{pH}$ 7). After transport to the lab, two $4 \mathrm{ml}$ aliquots of preserved samples were collected onto separate $25 \mathrm{~mm}$ black polycarbonate $0.2-\mu \mathrm{m}$ pore size Isopore membrane filters (Millipore, Billerica, MA, USA) and washed with $\operatorname{diH}_{2} \mathrm{O}$. Filters were stained with $200 \mu \mathrm{l}$ of $1 \mu \mathrm{g} \mathrm{ml}^{-1} 4^{\prime}$,6-diamidino-2phenylindole (DAPI) solution for $10 \mathrm{~min}$ in the dark, washed with $18.2 \mathrm{M} \Omega \mathrm{H}_{2} \mathrm{O}$ and examined with a BX51 epifluorescence microscope (Olympus, Center Valley, PA, USA). Twenty fields were counted on each filter by three investigators. The minimum and maximum values for each filter were removed before averaging.

\section{Enrichment cultures}

Five-milliliter aliquots of sample were removed in gas-tight syringe and stored in sealed, $\mathrm{N}_{2}$-flushed serum bottles. Enrichments of $0.5 \mathrm{ml}$ sample in $4.5 \mathrm{ml} 0.2 \mu \mathrm{m}$-filtered lake water were prepared in Hungate tubes with two conditions: (a) addition of $100 \times$ yeast extract-acetate medium $(0.1 \%$ yeast extract, $0.1 \% \mathrm{Na}$ acetate, $32.5 \mathrm{mM}\left(\mathrm{NH}_{4}\right)_{2} \mathrm{SO}_{4}, 2 \mathrm{mM}$ $\mathrm{KCl}, 1 \mathrm{mM} \mathrm{K}_{2} \mathrm{HPO}_{4}, 0.7 \mathrm{mM} \mathrm{MgSO}{ }_{4}, 0.06 \mathrm{mM} \mathrm{KNO}_{3}$ and $0.06 \mathrm{mM} \mathrm{CaSO}_{4}$ ) to $0.01 \%$ concentration, vitamin solution, Balch element solution (Balch et al., 1979), $S^{0}$ (a few grains) and resazurin $(0.0045 \%)$, and incubation with $\mathrm{N}_{2}$ headspace; (b) same as (a) but under aerobic conditions (ambient headspace). Enrichments of $0.5 \mathrm{ml}$ sample plus $4.5 \mathrm{ml}$ sterile water were performed under two other conditions: (c) addition of $100 \times$ yeast extract-acetate medium to $1 \%$ and incubation with $\mathrm{H}_{2} / \mathrm{CO}_{2}(80 / 20 \%)$; and (d) same as (c) but incubation under aerobic conditions (ambient headspace). All incubations were performed at $3{ }^{\circ} \mathrm{C}$ in the dark. Serial dilutions were made $\left(0.9 \mathrm{ml}\right.$ sterile $\mathrm{H}_{2} \mathrm{O}, 0.1 \mathrm{ml}$ yeast extractacetate medium $+\mathrm{S}^{0}$ ) under both aerobic and anaerobic conditions at $3{ }^{\circ} \mathrm{C}$. Enrichments prepared as in (a) and (b) were also incubated at $60^{\circ} \mathrm{C}$. Enrichment and medium for incubation at $80{ }^{\circ} \mathrm{C}$ were prepared as described by Marteinsson et al. (2001a) with $\mathrm{pH}$ adjusted to 7.0 .

DNA-based clone library construction and $16 S$ rRNA gene sequencing

Samples $(250 \mathrm{ml})$ or enrichment cultures $(5 \mathrm{ml})$ were filtered through $25 \mathrm{~mm}$ polycarbonate $0.2-\mu \mathrm{m}$ pore size Nucleopore polycarbonate membrane filters (Whatman, Maidstone, Kent, UK). Filters were stored in DNA extraction buffer $(0.1 \mathrm{M} \mathrm{pH} 8.0$ Tris buffer, $0.1 \mathrm{M} \mathrm{pH} 8.0$ Na-EDTA, $0.1 \mathrm{M}$ phosphate buffer, $1.5 \mathrm{M} \mathrm{NaCl}$ and $0.5 \%$ cetyl trimethyl ammonium bromide) at $-80^{\circ} \mathrm{C}$. DNA extraction from filters was performed as described by Marteinsson et al. (2001b). DNA was also extracted from $1.5 \mathrm{ml}$ of sample that was centrifuged, the pellet re-suspended in lysis buffer consisting of Tris buffer (50 mM, pH 7.6), EDTA (1 mM, pH 8.0), 0.5\% Tween-20 (Sigma-Aldrich, St Louis, MO, USA) and $200 \mu \mathrm{g} \mathrm{ml}^{-1}$ proteinase $\mathrm{K}$, the buffer incubated for $2 \mathrm{~h}$ at $55^{\circ} \mathrm{C}$ and then heated to $95{ }^{\circ} \mathrm{C}$ for $5 \mathrm{~min}$. PCR was performed with the following primers: $9 \mathrm{~F}\left(5^{\prime}-\right.$ GAGTTTGATCCTGGCTCAG-3') and 1544R (5'-AGA AAGGAGGTGATCCA-3') for bacteria, and 23FLP (5'-GCGGATCCGCGGCCGCTGCAGAYCTGGTYGAT YCTGCC- $3^{\prime}$ ) and 1391R (5'-GACGGGCGGTGTGTR CA-3') for archaea using the protocol of Skírnisdóttir et al. (2000). PCR products were cloned directly using a TOPO TA cloning kit according to the manufacturer's instructions (Invitrogen, Carlsbad, CA, USA). Plasmid DNA from single colonies was isolated and sequenced using the BigDye Terminator Cycle Sequencing Ready Reaction Kit on an ABI sequencer (Applied Biosystems, Foster City, CA, USA) using the reverse primer 805R (5'-GACT ACCCGGGTATCTAATCC- $3^{\prime}$ ). Taxonomic assignments and identification of closest cultivated relatives were performed with the Ribosomal Database Project Classifier (Wang et al., 2007) and NCBI BLASTn. These sequence data have been submitted to the GenBank database under accession numbers FJ229496-FJ229759 and F232072-FJ232141.

\section{Pyrosequencing}

Approximately $0.15 \mu \mathrm{g}$ of DNA was extracted from each of the two halves of a filter using the same protocol as above. Pyrosequencing of $70 \mathrm{bp}$ of the V6 variable region in the 16S rRNA gene was performed with a GS-FLX (Roche, Basel, Switzerland) at the Marine Biological Laboratory, Woods Hole, USA. The V6 region contains sufficient sequence information to make taxonomic assignments to the genus level, provided certain quality criteria are met and there are closely related sequences in a database (Huse et al., 2008). Presence of suitable template was first verified by amplification using the primers 967F (5'-CAACGCGAAGAACCTTACC- $\left.3^{\prime}\right)$ and 1046R (5'-CGACAGCCATGCANCACCT- $\left.3^{\prime}\right)$. These were the bacteria-specific primers used for pyrosequencing minus the linker sequence and 4-base 'barcode' for parallel sample processing. Tags with one or more ambiguous base calls, those shorter than 60 bases and those encountering the proximal primer were discarded by the pipeline analysis software (Sogin et al., 2006). Unique tags may represent distinct phylotypes and were assigned taxonomic affiliations (down to genus level, 
if possible) by the process described in Sogin et al. (2006). However, tags derived from the same phylotype might be separately enumerated because they are of different length or cover slightly different regions of the V6 region. A Perl script written by EG constructed a minimum set of ribotypes for each taxon by grouping tags with identical overlapping sequences. A tag that could be assigned to more than one ribotype was assigned to the one with the greatest number of reads. Ribotypes with the same taxonomic affiliation may represent different strains or species, depending on resolution. These data have been submitted to the NCBI Short Read Archive as SRA002254.

\section{FISH probes}

We used bacterial and archaeal probes EUBI/338, EUBII, EUBIII (Daims et al., 1999), ARC-915 (Stahl and Amann, 1991) and ARC-344 (Raskin et al., 1994). Probes targeting the four most abundant phylotypes in our clone libraries (Acetobacterium, Paludibacter, Sulfuricurvum and Sulfurospirillum) were developed using PRIMER3 (Rozen and Skaletsky, 2000), checked for specificity with PRIMROSE (Ashelford et al., 2002) and ProbeCheck (Loy et al., 2007) using the SILVA database (Pruesse et al., 2007), and evaluated for access to the ribosome (Behrens et al., 2003) (Table 1). Positive controls (no mismatches) were prepared for all probes using actively growing pure or enrichment cultures (Table 1). As a positive control for our Sulfuricurvum probe, we used a formaldehyde-preserved subculture from a chloroethene-degrading enrichment that had produced a perfectly matching sequence (GenBank accession no. EU498374). Negative controls (one mismatch) were used for the Acetobacterium and Sulfurospirillum probes (Table 1). Probes were assayed over the stringency range $0-40 \%$ in $5 \%$ intervals. Stringencies that maximized counts in the positive controls and minimized false positives in the negative controls are reported in Table 1.
Fluorescent in situ hybridization

Paraformaldehyde-preserved samples (5-23 ml) were filtered and washed $\left(\operatorname{diH}_{2} \mathrm{O}\right)$ on 25- and 47-mm white Isopore polycarbonate membrane filters (Millipore). Filters were air dried in a laminar flow hood and stored at $-20^{\circ} \mathrm{C}$. To permeabilize membranes of archaea and Gram-positive bacteria, selected filter sections were overlaid with $0.2 \%$ low melting-point agarose, incubated with $0.01 \%$ lysozyme (Acros Organics, Geel, Belgium) at $37^{\circ} \mathrm{C}$ for 30-90 min, rinsed with $\mathrm{diH}_{2} \mathrm{O}$, stopped with $0.01 \mathrm{~N}$ $\mathrm{HCl}$ for $10 \mathrm{~min}$ and rinsed again with $\operatorname{diH}_{2} \mathrm{O}$. Sections of filters were hybridized with $18 \mu \mathrm{l}$ of hybridization buffer (0-40\% formamide, $0.9 \mathrm{M} \mathrm{NaCl}$, $20 \mathrm{mM}$ Tris- $\mathrm{HCl}$ and $0.01 \%$ SDS) and $2 \mu \mathrm{l}$ of $\mathrm{Cy}-3-$ labeled oligonucleotide probe $\left(50 \mathrm{ng} \mu \mathrm{l}^{-1}\right.$; Thermo Fisher Scientific, Ulm, Germany), sealed between glass slides and incubated in the dark at $46^{\circ} \mathrm{C}$ for $2-3 \mathrm{~h}$. Afterwards, the filters were immediately placed in $5 \mathrm{ml}$ wash buffer $(900-55 \mathrm{mM} \mathrm{NaCl}$, $20 \mathrm{~mm}$ Tris- $\mathrm{HCl}$ and $0.01 \%$ SDS) and incubated for $15 \mathrm{~min}$ at $48{ }^{\circ} \mathrm{C}$ with occasional inversion. Filter sections were washed in $\mathrm{diH}_{2} \mathrm{O}$, air dried in the dark for $15 \mathrm{~min}$, counter stained with $30 \mu \mathrm{l}$ of DAPI solution $\left(1 \mu \mathrm{g} \mathrm{ml}^{-1}\right)$ for $2 \mathrm{~min}$, successively washed in $\operatorname{diH}_{2} \mathrm{O}, 80 \%$ ethanol and $\operatorname{diH}_{2} \mathrm{O}$, and then air dried on filter paper for $1 \mathrm{~h}$ in the dark. Sections were mounted on glass slides with $10 \mu \mathrm{l}$ of antifading solution (Citifluor, London, UK) and examined with a BX-51 epifluorescence microscope (Olympus). Probed and DAPI-stained cells were counted in at least 10 fields in sections from at least two filters. These were compared with counts from a filter section hybridized with a nonsense probe (Table 1).

\section{Results}

Direct (DAPI) cell counts were $4.7-5.7 \times 10^{5}$ per ml. The combination of EUBI-III probes hybridized to $94 \pm 5 \%$ of DAPI cells on filters prepared 1 month after preservation. No cells $(<2 \%)$ were detected

Table 1 Oligonucleotide probes for fluorescent in situ hybridization experiments

\begin{tabular}{|c|c|c|c|c|}
\hline Name & Sequence $\left(5^{\prime}-3^{\prime}\right)$ & +Control & -Control & $\begin{array}{c}\text { Optimal } \\
\text { stringency }(\%)\end{array}$ \\
\hline EUBI & GCTGCCTCCCGTAGGAGT & & & 35 \\
\hline EUBII & GCAGCCACCCGTAGGTGT & & & \\
\hline EUBIII & GCTGCCACCCGTAGGTGT & & & \\
\hline ARC-915 & GTGCTCCCCCGCCAATTC & & & $10-20$ \\
\hline ARC-344 & TCGCGCCTGCTGCICCCCGT & & & 20 \\
\hline Aceto125 & TCCAAAGGGTAGGTTACCCA & $\begin{array}{l}\text { Acetobacterium bakii } \\
\text { (DSM 8239) }\end{array}$ & $\begin{array}{l}\text { Acetobacterium carbonolicum } \\
\text { (DSM 2925) }\end{array}$ & 15 \\
\hline Sspirill572 & TTCCAGCCTACGCATCCTTT & $\begin{array}{l}\text { Sulfurospirillum halorespirans } \\
\text { (DSM 13726) }\end{array}$ & $\begin{array}{l}\text { Sulfurospirillum deleyanium } \\
\text { (DSM 6946) }\end{array}$ & 40 \\
\hline Scurvum731 & GTATCATCCCAGCAGATCGC & Enrichment culture & None & \\
\hline Palud672 & CCGCTACACAACACATTCCG & $\begin{array}{l}\text { Paludibacter propionicigenes } \\
\text { (DSM ) }\end{array}$ & None & 20 \\
\hline Nonsense & ACTCCTACGGGAGGCAGC & & & \\
\hline
\end{tabular}


with archaea-specific probes. Only $64-76 \%$ of cells on other filters prepared after 4 months of preservation hybridized with the (bacterial-specific) EUBIIII probes, possibly reflecting ribosome degradation (Lam and Cowen, 2004), and these filters were not used further.

Bacterial-specific PCR amplification and gel electrophoresis of two independent DNA extracts for pyrosequencing generated not only a product with the expected length of about $145 \mathrm{bp}$ but also a shorter doublet at around $100 \mathrm{bp}$ (data not shown). These lengths include the uninformative linker, barcode and primer. Archaea-specific amplification and pyrosequencing were not attempted because archaea were not detected by full-length PCR or FISH. Pyrosequencing of the bacterial products yielded an unexpectedly small number of reads and an anomalously large fraction of short reads $(<50$ bases when trimmed) that were rejected by the processing pipeline. In all, $52 \%$ and $63 \%$ of reads from the first and second extractions/reactions were rejected by the pipeline filter because they were shorter than 50 bases, had at least one indeterminate base call or encountered the proximal primer. We presume that the numerous short reads were related to the presence of the doublet. Although some matched rRNA gene sequences, others consisted of one or two copies of the 967F primer, suggesting an anomalous chemistry during DNA processing or amplification. In all, 2368 and 6984 reads from the first and second reactions passed the pipeline filter. We excluded 394 reads (210 unique tags) with GAST distances $>0.25$ and spurious taxonomic assignments (Huse et al., 2008). Many have significant BLASTn hits to non-ribosomal genomic DNA and may be a result of nonspecific amplification. The remaining 8958 reads were grouped into 1065 unique tags.

We identified 69 tags $(7253$ reads, $81 \%$ of the total) that appeared in both libraries and that we consider most reliable. These represent 19 genera and 6 families, plus one member of the proteobacteria of uncertain affiliation and two members of the bacteria of unknown taxonomic identity. In Table 2, we report the number of reads assigned to each taxon, the total number of tags and the number of unique ribotypes. The fractional number of reads is plotted in Figure 3. The four most enumerated

Table 2 Major bacterial phylotypes in west Skaftá lake DNA

\begin{tabular}{|c|c|c|c|c|c|}
\hline Taxon (class) & $\operatorname{Reads}^{\mathrm{a}}$ & Tags & Ribotypes & Clones & $\begin{array}{c}\text { FISH } \\
(\%)\end{array}$ \\
\hline $\begin{array}{l}\text { Acetobacterium (Clostridia) } 98 \% \text { identity with Acetobacterium bakii } \\
\text { (Kotsyurbenko et al., 1995) }\end{array}$ & $5710(5076)$ & 334 & 21 & 141 & 10 \\
\hline Thermus (Thermus-Deinococcus) & $872(713)$ & 116 & 12 & 0 & \\
\hline $\begin{array}{l}\text { Paludibacter (Bacteroidetes) 溇 } 89 \% \text { identity with Paludibacter propionicigenes } \\
\text { (Ueki et al., 2006) }\end{array}$ & $762(700)$ & 51 & 2 & 24 & 27 \\
\hline $\begin{array}{l}\text { Sulfuricurvum ( } \varepsilon \text {-proteobacteria) } 95 \% \text { identity with Sulfuricurvum kujiense } \\
\text { (Kodama and Watanabe, 2004) }\end{array}$ & 249 (199) & 25 & 1 & 66 & 39 \\
\hline Pseudomonas ( $\gamma$-proteobacteria) & $126(104)$ & 18 & 1 & 0 & \\
\hline $\begin{array}{l}\text { Sulfurospirillum (e-proteobacteria) 98\% identity with Sulfurospirillum halorespirans } \\
\text { (Luijten et al., 2003) }\end{array}$ & $125(92)$ & 24 & 1 & 30 & 25 \\
\hline Desulfosporosinus (Clostridia) & $99(92)$ & 22 & 5 & 0 & \\
\hline $\begin{array}{l}\text { Geobacteraceae ( } \delta \text {-proteobacteria) } 96 \% \text { identity with Geobacter psychrophilus } \\
\text { (Nevin et al., 2005) }\end{array}$ & $54(49)$ & 6 & 1 & 1 & \\
\hline Enterobacteriaceae ( $\gamma$-proteobacteria) & $47(43)$ & 6 & 2 & 0 & \\
\hline Ralstonia ( $\beta$-proteobacteria) & $35(32)$ & 4 & 1 & 0 & \\
\hline Thermoanaerobacter (Clostridia) 垱 & $34(29)$ & 7 & 2 & 0 & \\
\hline Peptococcaceae (Clostridia) & $25(20)$ & 5 & 1 & 0 & \\
\hline Exiguobacterium (Bacilli) & $18(16)$ & 3 & 1 & 0 & \\
\hline Acidaminococcaceae (Clostridia) & $17(16)$ & 3 & 2 & 0 & \\
\hline Acinetobacter ( $\gamma$-proteobacteria) & $17(9)$ & 6 & 2 & 0 & \\
\hline Microbacteriaceae (Actinobacteria) & $14(8)$ & 5 & 1 & 0 & \\
\hline Staphylococcus (Bacilli) & $12(7)$ & 5 & 1 & 0 & \\
\hline Desulfobulbaceae ( $\delta$-proteobacteria) & $11(6)$ & 6 & 1 & 0 & \\
\hline Bacillus (Bacilli) & $11(7)$ & 4 & 1 & 0 & \\
\hline Diaphorobacter ( $\beta$-proteobacteria) & $10(10)$ & 1 & 1 & 0 & \\
\hline Microbacterium (Actinobacteria) & $8(7)$ & 2 & 1 & 0 & \\
\hline Desulfocapsa (ס-proteobacteria) & $7(7)$ & 1 & 1 & 1 & \\
\hline Streptococcus (Bacilli) & $7(3)$ & 4 & 1 & 0 & \\
\hline Gardnerella (Actinobacteria) & $5(4)$ & 2 & 1 & 0 & \\
\hline Clostridium (Clostridia) & $3(2)$ & 2 & 1 & 0 & \\
\hline Micrococcus (Actinobacteria) & $3(2)$ & 2 & 1 & 0 & \\
\hline Phylum proteobacteria & $9(3)$ & 6 & 1 & 0 & \\
\hline Domain bacteria & $47(11)$ & 26 & 2 & 0 & \\
\hline
\end{tabular}

Abbreviation: FISH, fluorescent in situ hybridization.

Dark-shaded rows correspond to groups of obligate anaerobes, whereas light-shaded rows correspond to facultative anaerobes. The indicates a relationship with a psychrotolerant or psychrophilic organism and the 潾 indicates a candidate thermophile.

${ }^{a}$ Number of reads assigned to ribotypes that appear in two independent libraries is in parentheses. 


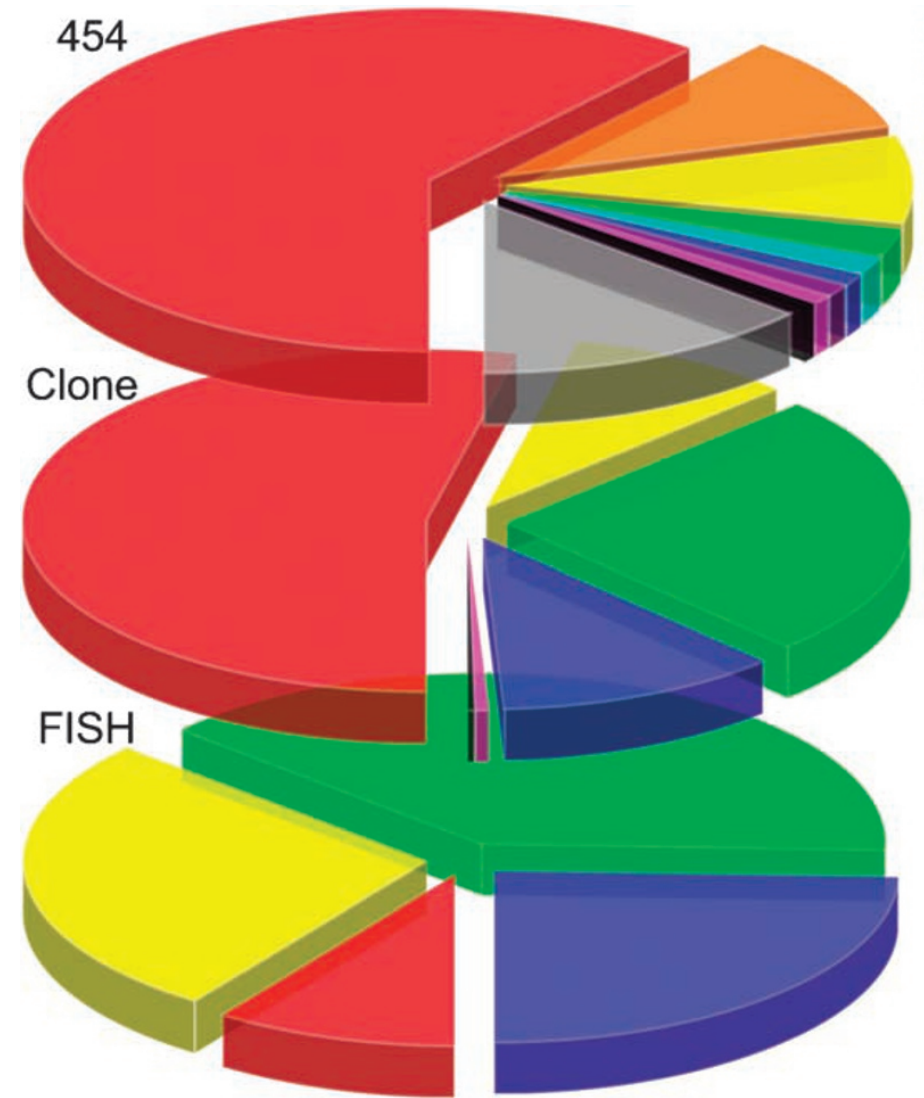

Acetobacterium

Thermus

Paludibacter

Sulfuricurvum

Pseudomonas

- Sulfurospirillum

- Desulfosporosinus

- TM-7

Geobacteraceae

Other

Figure 3 Distribution of 8958 reads of the rRNA gene V6 region (top), 264 partial-length rRNA clone library sequences (middle) and FISH-probed cells (bottom) in DNA libraries and filters prepared from the lake sample. FISH, fluorescent in situ hybridization.

phylotypes (including 36 ribotypes) account for $85 \%$ of all reads and $64 \%$ are included in a single cluster of 21 ribotypes affiliated with the genus Acetobacterium. Two hundred and thirty-two other tags (695 reads) were represented by at least two reads in one library, but their absence in the other is a low-significance ( $>5 \%$ probability) event that can be ascribed to chance rather than pyrosequencing error or contamination of one sample (Supplementary Information and Table S2.) They represent 25 genera, 11 families and taxonomically unresolved members of eight orders, three classes $(\alpha-, \gamma$ - and $\delta$-proteobacteria) and one phylum (Bacteroidetes). Seven hundred and nineteen more tags appeared as single reads in our combined libraries (data not shown).

We sequenced 264 clones from a library of $16 \mathrm{~S}$ rRNA gene fragments amplified using bacteriaspecific primers. These sequences represent seven phylotypes (Table 2 and Figure 3 ) corresponding to those identified by pyrosequencing (genera Acetobacterium, Paludibacter, Sulfuricurvum, Sulfurospirillum Geobacter, Desulfocapsa and the TM7 division). The Acetobacterium-related clones are divided between two ribotypes and together account for 53\% of all sequenced clones. All PCRs with archaea-specific primers failed.
Growth was observed in all enrichment cultures after 2 weeks of incubation at $3{ }^{\circ} \mathrm{C}$. No growth was observed in the $60{ }^{\circ} \mathrm{C}$ and $80^{\circ} \mathrm{C}$ incubations or in control samples. The highest growth was observed in enrichments initially prepared with filtered lake water rather than sterile $\mathrm{H}_{2} \mathrm{O}$. Microscopy revealed coccoid cells and both long, thin and short rods. Attempts to isolate pure strains from enrichments were unsuccessful. Libraries were constructed from DNA extracted from enrichments (b), (c) and (d), and 24, 22 and 24 clones, respectively, were sequenced. These included Sulfuricurvum and Sulfurospirillum sequences identical to those recovered from the lake sample, as well as three phylotypes not seen in the lake (Table S2).

All phylotype-specific fluorescent oligonucleotide probes hybridized to morphologically distinguishable cells (Figure 4). The Acetobacteriumspecific probe targeted spherical cells $1 \mu \mathrm{m}$ in diameter that were usually in attached pairs but sometimes alone or in chains of several cells. Our culture of Acetobacterium bakii (the closest culture relative) contained cells of similar size in doublets or chains, but the cells were more coccoid. The Paludibacter-specific probe targeted coccoid cells that appeared to be in linked chains, similar in morphology but longer 

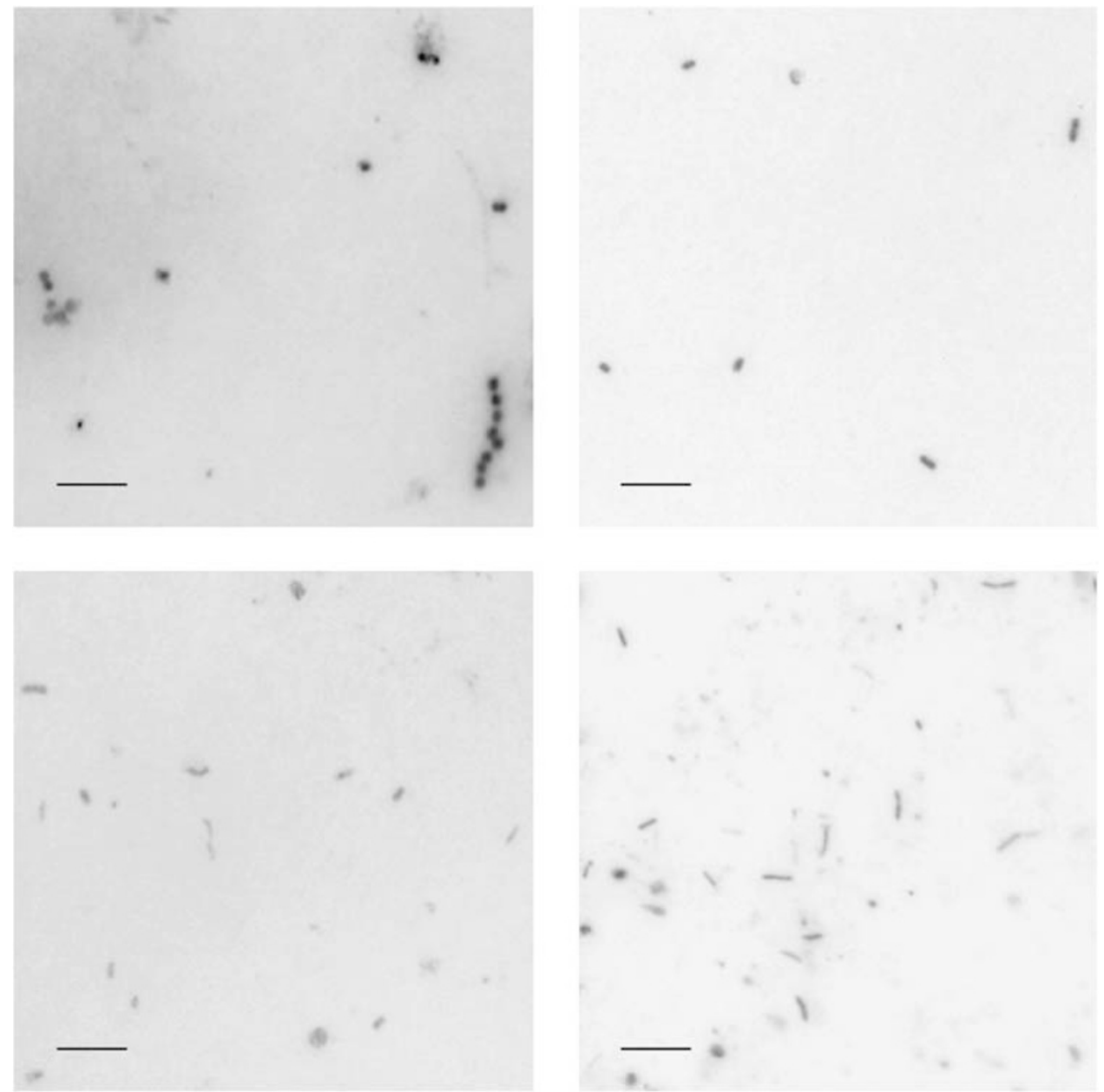

Figure 4 Images of cells hybridized by highly specific fluorescent oligonucleotide probes designed from sequences in our $16 \mathrm{~S}$ rRNA gene clone libraries. Clockwise from top left: Acetobacterium-, Sulfuricurvum-, Sulfurosprillum- and Paludibacter-specific hybridizations. Each scale bar is $5 \mu \mathrm{m}$.

than the P. kujiense. The Sulfuricurvum-specific probe hybridized to $1.8-\mu \mathrm{m}$ long rods; most were straight but a minority were curved like those of Sulfuricurvum kujiense (Kodama and Watanabe, 2004) and the cells detected in the enrichment culture. The Sulfurospirillum-specific probe hybridized to $2.3-\mu \mathrm{m}$ long rods that were thinner than the Sulfuricurvum-like cells. These four phylotypes account for essentially all DAPI-stained cells but errors permit $10-20 \%$ to belong to other phylotypes (Figure 3 and Table 2).

\section{Discussion}

Our data unequivocally show that bacteria dominate in the bottom water but do not completely rule out the presence of archaea. They reveal an oligarchic assemblage of bacteria, with a few phylotypes comprising the vast majority of cells and rRNA operon pool. However, there are discrepancies between our data sets. Each phylotype in our clone library is represented by multiple V6 reads from the same genus or family, but the reverse is not true (that is, genera Thermus, Pseudomonas and Desulfosporosinus). Our FISH investigation limited the missing phylotypes to not more than $10-20 \%$ of cells and did not identify morphologically distinctive cells stained by DAPI or hybridized with the EUBI-III probes but not targeted by our more specific probes. The apparent paucity of Thermus full-length clones relative to V6 tags is unlikely to be due to inadequate PCR primer coverage or bias in clone library construction because our primers target Thermus thermophilus and the same procedures were used to assay Thermus diversity elsewhere (Skírnisdóttir et al., 2000). The two cultivated strains most closely related to the Thermus-like V6 tags, $T$. igniterrae and $T$. antranikianii, are distinctive short rods or filaments $0.5-0.8 \mu \mathrm{m}$ wide (Chung et al., 2000). The cells belonging to these phylotypes could have been hidden on the mineral grains seen in our sample, or their DNA did not come from intact cells. These discrepancies highlight the importance of using multiple approaches to describe microbial assemblages. 
Hypothetical metabolisms and physicochemical tolerances of the organisms that these major phylotypes represent can be inferred from those of cultivated close relatives, although these inferences should be viewed with caution. Many phylotypes belong to groups composed of obligate and/or facultative anaerobes (Table 2) consistent with bottom water anoxia. Several phylotypes from the sample and enrichments are related to known psychrophilic or psychrotolerant organisms (Table 2) (Kotsyurbenko et al., 1995; Frühling et al., 2002; Finneran et al., 2003; Nevin et al., 2005; Chaturvedi and Shivaji, 2006; Rodrigues et al., 2006; Rodrigues and Tiedje, 2006) and suggest an adaptation to nearfreezing conditions. Phylotypes affiliated with Thermus and Thermoanaerobacter, genera comprising thermophiles and including closely related isolates from Icelandic hot springs (Chung et al., 2000), may have originated in hot springs elsewhere in the lake; alternatively, the genera could contain cold-tolerant species (Sheridan et al., 2003).

The majorities of both V6 reads and 16S rRNA gene clones are affiliated with the genus Acetobacterium, but a comparatively small fraction $(10 \%)$ of cells hybridized with our Acetobacterium-specific probe. These probes were designed using both clone ribotypes, and the distinctive morphology of acetobacteria makes it unlikely that cells were missed. Rather, their over-representation in our libraries may be a consequence of extraction/PCR bias or a high number of rRNA operons per cell. Some members of the Clostridium (in the order Clostridiales along with Acetobacterium) have $\geqslant 10$ rRNA operons (Rainey et al., 1996; Brüggemann et al., 2003; Acinas et al., 2004; Sadeghifard et al., 2006).

Both Acetobacterium ribotypes in our clone library are closely (98\% identity) related to A. bakii, an obligately anaerobic, psychrotolerant (growth at $1-30{ }^{\circ} \mathrm{C}$ ) homoacetogen (Kotsyurbenko et al., 1995) that extracts energy from the conversion of $\mathrm{H}_{2}$ and $\mathrm{CO}_{2}$ to acetate $\left(\mathrm{CH}_{3} \mathrm{COOH}\right)$. The genera Sulfuricurvum and Sulfurospirillum are also abundant in our V6 tag and clone libraries, and together comprise $64 \%$ of DAPI-stained cells (Table 2 and Figure 3). S. kujiense (Kodama and Watanabe, 2004) and Sulfurospirillum halorespirans (Luijten et al., 2003), the closest cultivated isolates, use sulfur compounds during chemotrophic growth; each belongs to a separate clade within the $\varepsilon$-proteobacteria, a class that is ubiquitous in sulfidic environments. S. kujiense uses elemental sulfur, sulfide and thiosulfate as electron donors during microaerobic $\left(1 \% \mathrm{O}_{2}\right)$ and anaerobic respiration, consistent with the presence of Sulfuricurvum sp. in both our aerobic and anaerobic enrichments. The Icelandic isolates related to our Thermus phylotypes also obtain energy from the aerobic oxidation of thiosulfate to sulfate (Skírnisdóttir et al., 2001). In contrast, related Sulfurospirillum spp. use sulfite, thiosulfate and elemental sulfur as terminal electron acceptors and $\mathrm{H}_{2}$ and organics as electron donors in energy- conserving reactions that reverse those catalyzed by S. kujiense (Luijten et al., 2003).

Some members of the genera Ralstonia, Pseudomonas and Enterobacteriaceae, represented by numerous reads in our V6 tag libraries, as well as $S$. kujiense and $S$. halorespirans, are capable of microaerobic hydrogen oxidation (Aragno, 1998; Luijten et al., 2003; Kodama and Watanabe, 2004). A phylotype from our aerobic enrichments (Supplementary Table S2) is closely related to Thiobacillus plumbophilus, an aerobe capable of growth by oxidation of $\mathrm{H}_{2}$, as well as $\mathrm{H}_{2} \mathrm{~S}$ and $\mathrm{PbS}$ (Drobner et al., 1992). Other metabolisms are possible: the family Geobacteraceae appears as a single phylotype in both our V6 tag and clone libraries; the latter is related to Geobacter psychrophilus, an Fe(III)-reducing psychrophile (Nevin et al., 2005). A sequence in our aerobic enrichment cultures is closely related to Rhodoferax ferrireducens T118, a psychrotolerant facultative anaerobe that uses Fe(III) as a terminal electron acceptor (Finneran et al., 2003) and member of the (predominantly heterotrophic) Comamonadaceae family widespread in cold environments (Skidmore et al., 2005). Another abundant phylotype (27\% of cells) is related to Paludibacter propionicigenes, an obligate anaerobe capable of fermenting sugars to propionate, acetate and succinate (Ueki et al., 2006), but its potential biogeochemical role in the lake is unknown.

The inferred metabolisms of the dominant bacterial phylotypes can be understood in the context of a model of lake circulation and chemistry (Jóhannesson et al., 2007). The bottom water contained $30 \mathrm{mM} \mathrm{CO}_{2}$ and as much as $600 \mu \mathrm{M} \mathrm{H}_{2}$ (A Stefansson, personal communication), and under such conditions $\left(4^{\circ} \mathrm{C}, \mathrm{pH}=5.22\right.$, and assuming $\left.\left[\mathrm{CH}_{3} \mathrm{COO}^{-}\right]=1 \mu \mathrm{M}\right)$, acetogenesis is exergonic $\left(\Delta \mathrm{G}=-32 \mathrm{~kJ}\right.$ per mol $\mathrm{H}_{2}$, using constants in Kotsyurbenko et al. (2001)). Methanogenesis is also thermodynamically feasible $(\Delta \mathrm{G}=-42 \mathrm{~kJ}$ per mol $\mathrm{H}_{2}$, assuming atmospheric $\mathrm{pCH}_{4}$ ), and non-acetoclastic methanogens would compete with homoacetogens for $\mathrm{H}_{2}$. However, at $4{ }^{\circ} \mathrm{C}$ and $\mathrm{pH}_{2}>10 \mathrm{~Pa}$ $(0.07 \mu \mathrm{M})$, A . bakii outcompeted two psychrotolerant methanogens isolated from the same environment (Kotsyurbenko et al., 2001). This could explain the abundance of acetogens and our inability to detect methanogens (exclusively archaea). Alternatively, methanogens, all strict anaerobes, might have been suppressed by the introduction of oxygen during bottom water formation. Mixing distinguishes this system from stratified, ice-covered Lake Fryxell where methanogens are abundant and active below the oxycline (Karr et al., 2006).

Sulfate reduction is important in many anoxic settings and some phylotypes in our libraries are affiliated with sulfate-reducing bacteria (SRB). These are Desulfosporosinus, a group of mesophilic, autotrophic, spore-forming sulfate reducers that can use hydrogen (Stackebrandt et al., 1997); the family Desulfobulbaceae, the members of which are strictly 
anaerobic, mesophilic or psychrophilic SRB (Kuever et al., 2005); and the sulfate-reducing genus Desulfocapsa (Table 2). The last is also represented by a $16 \mathrm{~S}$ rRNA gene clone sequence that is related to an isolate from a meromictic alpine lake (Peduzzi et al., 2003). Additional potential SRB (affiliates of Desulfuromonas, Desulforhopalus, Desulfuromusa and Desulfobacula) appear with much lower numbers of reads (Table S2). Although the reduction of sulfate to sulfide is exergonic under lake conditions (Conrad et al., 1986), with the exception of Desulfosporosinus, SRB do not constitute a significant fraction of cells or $16 \mathrm{~S}$ rRNA sequences. Sulfate reduction can be inhibited by a high $\mathrm{H}_{2} \mathrm{~S}$ level (Koschorreck, 2008) and/or limited by a low sulfate level (Holmer and Storkholm, 2001). Although the amount of sulfate $(0.16 \mathrm{mM})$ may be above the threshold for sulfate reduction, at least some of this may be the product of recent sulfide oxidation. Inhibition of SRB, which usually outcompete homoacetogens for $\mathrm{H}_{2}$, could explain the detection of hydrogen and the abundance of acetogens in the lake (Hoehler et al., 1999).

Jóhannesson et al. (2007) explained lake bottom water as a mixture of overlying sulfidic lake water with oxygenated glacial meltwater (Figure 2). On the basis of their model and assuming $\mathrm{O}_{2}$ saturation in the meltwater, bottom water would have initially contained both $1.2 \mathrm{mM} \mathrm{H}_{2} \mathrm{~S}+\mathrm{HS}^{-}$and $100 \mu \mathrm{M} \mathrm{O}$, a chemical disequilibrium able to support sulfideoxidizing bacteria. In the sample, detectable $(\geqslant 2 \mu \mathrm{M})$ $\mathrm{O}_{2}$ was absent and bottom water would have evolved to sulfide/oxygen ratios $\gg 12$ within a few days by abiotic oxidation alone (Millero, 2005). At sulfide/ oxygen ratios $>150$, biofilms of filamentous $\varepsilon$-proteobacteria replace the $\gamma$-proteobacteria groups Beggiatoa and Thiothrix in cave waters (Engel et al., 2004; Macalady et al., 2008), and many $\varepsilon$-proteobacteria such as $S$. kujiense are capable of microaerophilic growth at micromolar $\mathrm{O}_{2}$ (Kodama and Watanabe, 2004). Sulfide-oxidizing bacteria activity also explains the absence of detectable thiosulfate $\left(\mathrm{S}_{2} \mathrm{O}_{3}^{2-}\right)$ and sulfite $\left(\mathrm{SO}_{3}^{2-}\right)$, which would otherwise accumulate during abiotic sulfide oxidation (Millero, 2005).

Mixing of lake water and glacial meltwater would also have supported aerobic hydrogen oxidation by hydrogenotrophic bacteria. At $\left[\mathrm{H}_{2}\right]>0.1 \mathrm{nM}, \mathrm{H}_{2}$ oxidation is more exergonic per $\mathrm{O}_{2}$ molecule than sulfide oxidation (based on data in Bach and Edwards (2003)). The presence of $\mathrm{H}_{2}$-oxidizing clades has been correlated with the free energy of this reaction (Spear et al., 2005), but its importance vis-à-vis sulfide oxidation is probably controlled by the $\mathrm{H}_{2}$ affinities and uptake kinetics of guild members (D'Imperio et al., 2008). We speculate that hydrogen-oxidizing bacteria (possibly including Ralstonia sp.) were active earlier at a higher oxygen concentration, but have been replaced by organisms that use sulfur species as electron acceptors such as Sulfurospillum sp. This could explain why the former appeared in the DNA pool but did not constitute a significant fraction of DAPI-stained cells.

Numerous additional bacterial taxa were identified by V6 tags (Supplementary Table S2) and there is evidence for greater diversity at still lower abundance, including 719 single-red tags (data not shown). A rarefaction analysis showed that phylotype sampling did not reach saturation (Figure S2). The uncultivated division TM7 (Hugenholtz et al., 2001) is represented by both V6 tags and a single sequenced clone. Two phylotypes from our enrichment cultures (a Thiobacillus-related $\beta$-proteobacterium and a member of the Campylobacteraceae) have no counterparts in our other data and may represent failures of V6-based taxonomy, or rare, cultivable 'weeds'. These additional phylotypes cannot comprise more than $10-20 \%$ of DAPI-stained or EUBI-III-hybridized cells. Some may be dormant or slow-growing species released by melting of glacial ice but maladapted to the lake environment. Others may have dispersed from hot springs or lake sediment. Strikingly, most minor groups are proteobacteria, in contrast to the dominant groups that fall in classes Clostridia, Bacilli and Actinobacteria as well as proteobacteria (Table 2). The vast majority of sequences obtained from Grímsvötn samples were affiliated with the $\beta$-proteobacteria (Gaidos et al., 2004), a group widely recovered from freshwater (Methé et al., 1998), including cold oligotrophic lakes and melt ponds (Brinkmeyer et al., 2004), and the accretionary ice above Lake Vostok (Priscu et al., 1999).

As measured by particulate organic carbon (0.6 $\left.\mathrm{mg} \mathrm{l}^{-1}\right)$, the western Skaftá lake is oligotrophic and microbial autotrophy would control flows of carbon. The closest cultivated relatives of the Acetobacteria and Sulfuricurvum phylotypes are both autotrophs (Kotsyurbenko et al., 1995; Kodama and Watanabe, 2004) and that of the Sulfurospirillum sp. can use acetate as a carbon source (Luijten et al., 2003). Thus, acetogenesis may be another important entry point for carbon into this ecosystem. The bacterial oligarchy in this subglacial lake, where acetogens replaced methanogens, stands in contrast to hydrogen-dependent communities from highertemperature subsurface habitats where (methanogenic) archaea dominate (Chapelle et al., 2002). It is unclear whether the structure of this unique microbial assemblage is the result of ecological pressure or limited colonization by adapted microbes, but a comparison with the eastern Skaftá lake could prove illuminating.

\section{Acknowledgements}

This material is based upon work supported by the National Aeronautics and Space Administration through the NASA Astrobiology Institute under Cooperative Agreement no. NNA04CC08A issued through the Office 
of Space Science and by the Icelandic Centre for Research. The Icelandic National Energy Authority, National Power Company and Public Roads Administration provided logistical support. Members of the Icelandic Glaciological Society assisted in the field campaign on Vatnajökull. The NAI lead team at the Marine Biological Laboratory performed pyrosequencing, and Mitch Sogin, Hilary Morrison and Sue Huse assisted with procedures and analysis. Ruth Richardson provided an enrichment culture for FISH. Brian Popp and Terri Rust measured POM.

\section{References}

Acinas SG, Marcelino LA, Klepac-Ceraj V, Polz MF. (2004). Divergence and redundancy of $16 \mathrm{~S}$ rRNA sequences in genomes with multiple rrn operons. J Bacteriol 186: 2629-2635.

Ágústsdóttir AM, Brantley SL. (1994). Volatile fluxes integrated over four decades at Grímsvötn volcano, Iceland. J Geophys Res 99: 9505-9522.

Aragno M. (1998). The aerobic, hydrogen-oxidizing bacteria. In: Burlage RS, Atlas R, Stahl D, Geesey G and Sayler G (eds). Microbial Ecology. Oxford Univ. Press: Oxford, pp 79.

Ashelford KE, Weightman AJ, Fry JC. (2002). PRIMROSE: a computer program for generating and estimating the phylogenetic range of $16 \mathrm{~S}$ rRNA oligonucleotide probes and primers in conjunction with the RDP-II database. Nucleic Acids Res 30: 3481-3489.

Bach W, Edwards KJ. (2003). Iron and sulfide oxidation within the basaltic ocean crust: implications for chemolithoautotrophic microbial biomass production. Geochim Cosmochim Acta 67: 3871-3887.

Balch WE, Fox GE, Magrum LJ, Woese CR, Wolfe RS. (1979). Methanogens: reevaluation of a unique biological group. Microbiol Rev 43: 260-296.

Behrens H, Beims U, Dieter H, Dietze G, Eikmann T, Grummt T et al. (2001). Toxilogical and ecotoxilogical assessment of water tracers. Hydrogeol J 9: 321-325.

Behrens S, Rühland C, Inácio J, Huber H, Fonseca A, Spencer-Martins I et al. (2003). In situ accessibility of small-subunit rRNA of members of the domains Bacteria, Archaea, and Eukarya to Cy3-labeled oligonucleotide probes. Appl Environ Microbiol 69: 1748-1758.

Björnsson H. (2002). Subglacial lakes and jökulhlaups in Iceland. Glob Planet Change 35: 255-271.

Brinkmeyer R, Glöckner F-O, Helmke E, Amann R. (2004). Predominance of $\beta$-proteobacteria in summer melt ponds on Arctic pack ice. Limnol Oceanogr 49: 1013-1021.

Brüggemann H, Bäumer S, Fricke WF, Wiezer A, Liesegang $\mathrm{H}$, Decker I et al. (2003). The genome sequence of Clostridium tetani, the causative agent of tetanus disease. Proc Natl Acad Sci USA 100: 1316-1321.

Chapelle FH, O’Neil K, Bradley PM, Methé BA, Ciufo SA, Knobel LL et al. (2002). A hydrogen-based subsurface microbial community dominated by methanogens. Nature 415: 312-314.

Chaturvedi P, Shivaji S. (2006). Exiguobacterium indicum sp. nov., a psychrophilic bacterium from the Hamta glacier of the Himalayan mountain ranges of India. Int J Syst Evol Microbiol 56: 2765-2770.

Chung AP, Rainey FA, Valente M, Nobre MF, da Costa MS. (2000). Thermus igniterrae sp. nov. and Thermus antranikianii sp. nov., two new species from Iceland. Int J Syst Evol Microbiol 50: 209-217.

Conrad R, Schink B, Phelps TJ. (1986). Thermodynamics of $\mathrm{H}_{2}$-consuming and $\mathrm{H}_{2}$-producing metabolic reactions in diverse methanogenic environments under in situ conditions. FEMS Microbiol Ecol 38: 353-360.

D’Imperio S, Lehr CR, Oduro H, Druschel GK, Kühl M, McDermott TR. (2008). Relative importance of H2 and H2S as energy sources for primary production in geothermal springs. Appl Environ Microbiol 74: 5802-5808.

Daims H, Bruhl A, Amann R, Schleifer KH, Wagner M. (1999). Probe EUB338 is insufficient for the detection of all Bacteria: development and evaluation of a more comprehensive probe set. Syst Appl Microbiol 22: 434-444.

Drobner E, Huber H, Rachel R, Stetter KO. (1992). Thiobacillus plumbophilus sp. nov., a novel galena and hydrogen oxidizer. Arch Microbiol 157: 213-217.

Engel AS, Porter ML, Stern LA, Quinlan S, Bennett PC. (2004). Bacterial diversity and ecosystem function of filamentous microbial mats from aphotic (cave) sulfidic springs dominated by chemolithoautotrophic 'Epsilonproteobacteria'. Appl Environ Microbiol 51: 31-53.

Farr TG. (2004). Terrestrial analogs to Mars: The NRC community decadal report. Planet Space Sci 52: 3-10.

Finneran KT, Johnson CV, Lovley DR. (2003). Rhodoferax ferrireducens sp. nov. a psychrotolerant, facultatively anaerobic bacterium that oxidizes acetate with the reduction of Fe(III). Int J Syst Evol Microbiol 53: 669-673.

Frühling A, Schumann P, Hippe H, Sträubler B, Stackebrandt E. (2002). Exiguobacterium tundrae sp. nov. and Exiguobacterium antarcticum sp. nov. Int $J$ Syst Evol Microbiol 52: 1171-1176.

Gaidos E, Glazer B, Harris D, Heshiki Z, Jeppsson N, Miller $\mathrm{M}$ et al. (2007). A simple sampler for subglacial water bodies. J Glaciol 53: 157-158.

Gaidos E, Lanoil B, Thorsteinsson T, Graham A, Skidmore M, Han S-k et al. (2004). A viable microbial community in a subglacial volcanic crater lake, Iceland. Astrobiology 4: 327-344.

Gaidos EJ, Nealson KH, Kirschvink JL. (1999). Life in icecovered oceans. Science 284: 1631-1633.

Hoehler TM, Albert DB, Alperin MJ, Martens CS. (1999). Acetogenesis from $\mathrm{CO} 2$ in an anoxic marine sediment. Limnol Oceanogr 44: 662-667.

Holmer M, Storkholm P. (2001). Sulphate reduction and sulphur cycling in lake sediments: a review. Freshwater Biol 46: 431-451.

Hugenholtz P, Tyson GW, Webb RI, Wagner AM, Blackall LL. (2001). Investigation of candidate division TM7, a recently recognized major lineage of the domain Bacteria with no known pure-culture representatives. Appl Environ Microbiol 67: 411-419.

Huse SM, Dethlefsen L, Huber JA, Welch DM, Relman DA, Sogin ML. (2008). Exploring microbial diversity and taxonomy using SSU rRNA hypervariable tag sequencing. PLoS Genet 4: e1000255.

Jensen M, Kristensen KK. (1999). Effects of rhodamine water tracer on Escherichia coli densities. Water Res 23: $257-259$.

Jóhannesson T, Thorsteinsson T, Stefánsson A, Gaidos E, Einarsson B. (2007). Circulation and thermodynamics in a subglacial geothermal lake under the Western 
Skaftá cauldron of the Vatnajökull ice cap, Iceland. Geophys Res Lett 34: L19502.

Karr EA, Ng JM, Belchik SM, Sattle WM, Madigan MT, Achenbach LA. (2006). Biodiversity of methanogenic and other Archaea in the permanently frozen Lake Fryxell, Antarctica. Appl Environ Microbiol 72: 1663-1666.

Kennicut Jr MC ed (2000). Subglacial lake exploration workshop report and recommendations Texas A \& M for the Scientific Committee on Antarctic Research, College Station, TX, USA.

Kodama Y, Watanabe K. (2004). Sulfuricurvum kujiense gen. nov., sp. nov., a facultatively anaerobic, chemolithoautotrophic, sulfur-oxidizing bacterium isolated from an underground crude-oil storage cavity. Int $J$ Syst Evol Microbiol 54: 2297-2300.

Koschorreck M. (2008). Microbial sulphate reduction at a low pH. FEMS Microbiol 64: 329-342.

Kotsyurbenko OR, Glagolev MV, Nozhevnikova AN, Conrad R. (2001). Competition between homoacetogenic bacteria and methanogenic archaea for hydrogen at low temperature. FEMS Microbiol Ecol 38: 153-159.

Kotsyurbenko OR, Simankova MV, Nozhevnikova AN, Zhilina TN, Bolotina NP, Lysenko AM et al. (1995). New species of psychrophilic acetogens: Acetobacterium bakii sp. nov., $A$. paludosum sp. nov., A. fimetarium sp. nov. Arch Microbiol 163: 29-34.

Kuever J, Rainey FA, Widdel F. (2005). Desulfobulbaceae fam. nov. In: Brenner DJ, Krieg NR and Staley JT (eds). Bergey's Manual of Systematic Bacteriology 2nd ed. Springer: NY, pp 988-992.

Lam P, Cowen JP. (2004). Processing deep-sea particle-rich water samples for fluorescence in situ hybridization: consideration of storage effects, preservations, and sonication. Appl Environ Microbiol 70: 25-33.

Loy A, Maixner F, Wagner M, Horn M. (2007). probeBasean online resource for rRNA-targeted oligonucleotide probes: new features 2007. Nucleic Acids Res 35: D800-D804.

Luijten MLGC, de Weert J, Smidt H, Boschker HTS, de Vos WM, Schraa G et al. (2003). Description of Sulfurospirillum halorespirans sp. nov., an anaerobic, tetrachloroethene-respiring bacterium, and transfer of Dehalospirillum multivorans to genus Sulfurospirillum as Sulfurospirillum multivorans comb. Int J Syst Evol Microbiol 53: 787-793.

Macalady JL, Dattagupta S, Schaperdoth I, Jones DS, Druschel GK, Eastman D. (2008). Niche differentiation among sulfur-oxidizing bacterial populations in cave waters. ISME J 2: 590-601.

Marteinsson VT, Hauksdóttir S, Hobel CF, Kristmannsdóttir H, Hreggvidsson GO, Kristjánsson JK. (2001a). Phylogenetic diversity analysis of subterranean hot springs in Iceland. Appl Environ Microbiol 67: 4242-4248.

Marteinsson VT, Kristjánsson JK, Kristmannsdóttir $H$, Sæmundsson K, Hannignton M, Petursdottir SK et al. (2001b). Discovery and description of giant submarine smectite cones on the seafloor of Eyjafjor$\mathrm{du}$, northern Iceland, and a novel thermal microbial habitat. Appl Environ Microbiol 67: 827-833.

Methé BA, Hieorns WD, Zehr JP. (1998). Contrasts between marine and freshwater bacterial community composition: analyses of communities in Lake George and six other Adirondack lakes. Limnol Oceanogr 43: 368-374.

Millero FJ. (2005). Chemical Oceanography. CRC Press: Boca Raton, FL.
Nevin KP, Holmes DE, Woodard TL, Heinlein ES, Ostendorf DW, Lovely DR. (2005). Geobacter bemidjiensis sp. nov. and Geobacter psychrophilus sp. nov., two novel Fe(III)-reducing subsurface isolates. Int $J$ Syst Evol Microbiol 55: 1667-1674.

Pasternack GB, Varekamp JC. (1997). Volcanic lake systematics I. Physical constraints. Bull Volcanol 58: 528-538.

Peduzzi S, Tonolla M, Hahn D. (2003). Isolation and characterization of aggregate-forming sulfate-reducing and purple sulfur bacteria from the chemocline of meromictic Lake Cadagno, Switzerland. FEMS Microbiol Ecol 45: 29-37.

Priscu JC, Adams EE, Lyons WB, Voytek MA, Mogk DW, Brown RL et al. (1999). Geomicrobiology of subglacial ice above Lake Vostok, Antarctica. Science 286: 2141-2144.

Pruesse E, Quast C, Knittel K, Fuchs BM, Ludwig W, Peplies J et al. (2007). SILVA: a comprehensive online resource for quality checked and aligned ribosomal RNA sequence data compatible with ARB. Nucleic Acids Res 35: 7188-7196.

Rainey FA, Ward-Rainey NL, Janssen PH, Hippe H, Stackebrandt E. (1996). Clostridium paradoxum DSM 7308T contains multiple 16S rRNA genes with heterogeneous intervening sequences. Microbiology 142: 2087-2095.

Raskin L, Stromley JM, Rittmann BE, Stahl DA. (1994). Group-specific 16S rRNA hybridization probes to describe natural communities of methanogens. Appl Environ Microbiol 60: 1232-1240.

Rodrigues DF, Goris J, Vishnivetskaya T, Gilichinsky D, Thomashow MF, Tiedje JM. (2006). Characterization of Exiguobacterium isolates from the Siberian permafrost. Description of Exiguobacterium sibericum sp. nov. Extremophiles 10: 285-294.

Rodrigues DF, Tiedje JM. (2006). Multi-locus real-time PCR for quantitation of bacteria in the environment reveals Exiguobacterium to be prevalent in permafrost. FEMS Microbiol Ecol 59: 489-499.

Rozen S, Skaletsky HJ. (2000). Primer3 on the WWW for general users and for biologist programmers. In: Krawetz S and Misener S (eds). Bioinformatics Methods and Protocols: Methods in Molecular Biology. Humana Press: Totowa, New Jersey, USA, pp 365-386.

Sadeghifard N, Gurler V, Beer M, Seviour RJ. (2006). The mosaic nature of intergenic 16S-23S rRNA spacer regions suggests rRNA operon copy number variation in Clostridium difficile strains. Appl Environ Microbiol 72: 7311-7323.

Sheridan PP, Miteva VI, Brenchley JE. (2003). Phylogenetic analysis of anaerobic psychrophilic enrichment cultures obtained from a Greenland glacier ice core. Appl Environ Microbiol 69: 2153-3160.

Siegert MJ, Carter S, Tabacco I, Popv S, Blankenship DD. (2005). A revised inventory of Antarctic subglacial lakes. Antarct Sci 17: 453-460.

Skidmore M, Anderson SP, Sharp M, Foght J, Lanoil BD. (2005). Comparison of microbial community compositions of two subglacial environments reveals a possible role for microbes in chemical weathering processes. Appl Environ Microbiol 71: 6986-6997.

Skírnisdóttir S, Hreggvidsson GO, Hjörleifsdottir S, Marteinsson VT, Petursdottir S, Holst O et al. (2000). Influence of sulfide and temperature on species composition and community structure of hot spring microbial mats. Appl Environ Microbiol 66: 2835-2841. 
Skírnisdóttir S, Hreggvidsson GO, Holst O, Kristjánsson JK. (2001). Isolation and characterization of a mixotrophic sulfur-oxidizing Thermus scotoductus. Extremophiles 5: $45-51$.

Sogin ML, Morrison HG, Huber JA, Welch DM, Huse SM, Neal PR et al. (2006). Microbial diversity in the deep sea and the underexplored 'rare biosphere'. Proc Natl Acad Sci USA 103: 12115-12120.

Spear JR, Walker JJ, Mccollom TM, Pace NR. (2005). Hydrogen and bioenergetics in the Yellowstone geothermal ecosystem. Proc Natl Acad Sci USA 102: 2555-2560.

Stackebrandt E, Sproer C, Rainey FA, Burghardt J, Päuker O, Hippe H. (1997). Phylogenetic analysis of the genus Desulfotomaculum: evidence for the misclassification of Desulfotomaculum guttoideum and description of Desulfotomatculum orientis as Desulfosporosinus orientis gen. nov., comb. nov. Int J Syst Bacteriol 47: 1134-1139.

Stahl DA, Amann R. (1991). Development and application of nucleic acid probes. In: Stackebrandt E and Good- fellow M (eds). Nucleic Acid Techniques in Bacterial Systematics. John Wiley \& Sons: Chichester, UK, pp 205-248.

Thorsteinsson T, Elefsen S, Gaidos E, Lanoil B, Jóhannesson T, Kjartansson V et al. (2008). A hot water drill with built-in sterilization: design, testing, and performance. Jökull 51: 71-82.

Ueki A, Akasaka H, Suzuki D, Ueki K. (2006). Paludibacter propionicigenes gen. nov., sp. nov., a novel strictly anaerobic, Gram-negative, propionate-producing bacterium isolated from plant residue in irrigated rice-field soil in Japan. Int J Syst Evol Microbiol 56: 39-44.

US National Research Council Committee on Principles of Environmental (2007). Stewardship for the Exploration and Study of Subglacial Environments. National Academies Press: Washington DC, 162pp.

Wang Q, Garrity GM, Tiedje JM, Cole JR. (2007). Naive Bayesian classifier for rapid assignment of rRNA sequences into the new bacterial taxonomy. Appl Environ Microbiol 73: 5261-5267.

Supplementary Information accompanies the paper on The ISME Journal website (http://www.nature.com/ismej) 